\title{
Article \\ Effects of Functionalization in Different Conditions and Ball Milling on the Dispersion and Thermal and Electrical Conductivity of MWCNTs in Aqueous Solution
}

\author{
Baasandulam Tserengombo $\left.^{1}{ }^{(}\right)$, Hyomin Jeong ${ }^{2}{ }^{(}$, Erdenechimeg Dolgor ${ }^{3}$, Antonio Delgado ${ }^{4,5}$ \\ and Sedong Kim ${ }^{4, *}$ \\ 1 Department of Energy and Mechanical Engineering, Graduate School, Gyeongsang National University, \\ Jinju 53064, Korea; baasandulam0902@gmail.com \\ 2 Department of Energy and Mechanical Engineering, Institute of Marine Industry, \\ Gyeongsang National University, Cheondaegukchi-Gil 38, Tongyeong 53064, Korea; hmjeong@gnu.ac.kr \\ 3 Department of Chemical and Biological Engineering, School of Engineering and Applied Science, \\ National University of Mongolia, P.O. Box 46A, Ulaanbaatar 14201, Mongolia; \\ erdenechimeg@seas.num.edu.mn \\ 4 German Engineering Research and Development Center LSTME Busan Branch, Busan 46742, Korea; \\ antonio.delgado@1stme.org \\ 5 Institute of Fluid Mechanics, Friedrich-Alexander Universität Erlangen-Nürnberg, 91058 Erlangen, Germany \\ * Correspondence: sedong.kim@lstme.org
}

Citation: Tserengombo, B.; Jeong, H.; Dolgor, E.; Delgado, A.; Kim, S. Effects of Functionalization in Different Conditions and Ball Milling on the Dispersion and Thermal and Electrical Conductivity of MWCNTs in Aqueous Solution. Nanomaterials 2021, 11, 1323. https://doi.org/ 10.3390/nano11051323

Academic Editors: Domenico De Tommasi, Fernando Fraternali and Raffaele Barretta

Received: 21 April 2021

Accepted: 13 May 2021

Published: 18 May 2021

Publisher's Note: MDPI stays neutral with regard to jurisdictional claims in published maps and institutional affiliations.

Copyright: (c) 2021 by the authors. Licensee MDPI, Basel, Switzerland. This article is an open access article distributed under the terms and conditions of the Creative Commons Attribution (CC BY) license (https:// creativecommons.org/licenses/by/ $4.0 /)$.

\begin{abstract}
In this work, the effects of a functionalization method involving different conditions and milling processes on the dispersion and thermal and electrical conductivity of multiwalled carbon nanotubes were studied. The surfaces of MWCNTs were modified using a mixture of sulfuric and nitric acid as an acid treatment and potassium persulfate and sodium hydroxide as an alkaline treatment to achieve more hydrophilic MWCNTs. The morphological and structural investigations were carried out using transmission electron microscopy and Fourier transform infrared spectroscopy. Furthermore, the dispersion characteristics and thermal and electrical conductivity of the as-prepared water-based nanofluids were measured. As a result, the dispersion characteristics revealed that the best dispersion and stability results were obtained for alkaline-treated MWCNTs using potassium persulfate and sodium hydroxide. The thermophysical study using a thermal conductivity analyzer exhibited that the thermal conductivity of the pristine MWCNT nanofluid $(0.1 \mathrm{wt} \%)$ was enhanced from 603.5 to $610.4 \mathrm{~mW} / \mathrm{m} \cdot \mathrm{K}$ and the electrical conductivity of the raw MWCNT nanofluid was increased from 16.2 to $125.8 \mu \mathrm{S} / \mathrm{cm}$ at $25^{\circ} \mathrm{C}$ after alkaline treatment and milling processes, which were performed using planetary ball milling. Regarding the overall results, the milling process and mild alkaline oxidation process are more environmentally friendly, effective, and convenient for the functionalization of CNTs, without requiring any organic solvents or strong acids.
\end{abstract}

Keywords: MWCNTs; functionalization; alkaline treatment; dispersion; thermal conductivity

\section{Introduction}

Carbon nanotubes (CNTs) have been highlighted since their discovery due to their unique structure and remarkable mechanical, thermal, and electrical characteristics, which make them excellent candidates in many fields [1-3]. Carbon nanotubes are promising materials for various applications, such as energy [4], biological and biomedical [5], environmental [6], composite material [7], electronic [8], optical [9], solar cell [10], and hydrogen storage [11] applications. However, the development of CNT applications has been impeded by their aggregation, as CNTs tend to agglomerate due to their large aspect ratio and van der Waals forces, which lead to dispersion difficulties in dispersion media [12,13].

Therefore, many studies have been focused on how to improve the dispersibility of CNTs. 
To solve dispersion problems, many approaches have been attempted, namely ultrasonication, mechanical milling, chemical functionalization, and addition of various surfactants and polymers; good dispersion in a homogeneous solution would expand the scope of their application and improve their properties. Munkhbayar et al. [14] studied the photovoltaic performance of dye-sensitized solar cells with various MWCNT counter electrodes. It was found that the dispersibility of CNT enhances with increasing photovoltaic efficiency. Garg et al. [15] reported an optimum ultrasonication time of $40 \mathrm{~min}$ to increase the thermal conductivity of $1 \mathrm{wt} \%$ MWCNT nanofluids. Krause et al. [16] studied ball-milled CNTs regarding their morphology and nanotube length. They found that when increasing the ball milling time significantly, this decreased the agglomerate size, shortened the length, and increased the surface area. Additionally, surfactants and polymers can be used to improve the dispersion of nanoparticles [17-19]. In our previous work [20], we compared the effects of the surfactants sodium dodecyl sulfate (SDS), sodium dodecyl benzene sulfonate (SDBS), and dodecyl betaine (DB) in aqueous solution regarding their effects on the dispersion and thermal conductivity of CNTs. We found that the dispersion of the nanofluid increased with increasing surfactant concentration; however, the thermal conductivity of the nanofluid with surfactant was lower than the nanofluid without surfactant. Low thermal conductivity may result from surfactant molecules adsorbing onto the surfaces of CNTs, thereby enlarging the resistance between the CNTs and the base fluid.

Nanotube functionalization is the most effective method to improve the dispersion of carbon materials. The functionalization of CNTs using chemical oxidation methods enhances the solubility by incorporating hydrophilic moieties onto the nanotubes. The functional groups are attached to the nanotube ends and side walls via covalent bond formation, thus resulting in more hydrophilic CNTs [21,22]. Oxidizing agents such as nitric acid, sulfuric acid, a mixture of sulfuric acid and nitric acid, potassium permanganate, sulfuric acid in the presence of potassium permanganate, hydrogen peroxide in the presence of nitric acid, hydrogen peroxide, and ozone [23-28] are used. Strong acids are the most used oxidants for the chemical functionalization of CNTs [29-31]. Acid treatment is effective for CNT functionalization, however it is environmentally unfriendly and leads to equipment corrosion. Recently, reports have emerged outlining a mild oxidation process under alkaline conditions, which is eco-friendlier and has no need for the use of organic solvents and strong acids [32,33].

To the best of the authors' knowledge, there is only one limited study comparing alkaline and acid treatment methods regarding their effects on the dispersion of MWCNTs. Therefore, in this experimental study, we compared alkaline treatment to conventional acid treatment and considered the effects of milling in terms of the dispersion characteristics, suspension stability, and thermal and electrical conductivity of MWCNT nanofluids.

\section{Experimental Details}

2.1. Materials

The Raw MWCNTs measuring $\sim 20 \mathrm{~nm}$ in diameter and $\sim 5 \mu \mathrm{m}$ in length, with greater than 95\% purity and less than 3\% impurities (Carbon Nanomaterial Technology Co., Ltd., Korea), were used in this experimental study.

Nitric acid $\left(\mathrm{HNO}_{3}\right)$ at a concentration of $63 \%$, sulfuric acid $\left(\mathrm{H}_{2} \mathrm{SO}_{4}\right)$ at a concentration of $98 \%$ (Junsei Chemicals Co., Ltd., Japan), potassium persulfate $\left(\mathrm{K}_{2} \mathrm{~S}_{2} \mathrm{O}_{8}\right)$ at greater than 99.0\% purity (Sigma-Aldrich Co., Ltd., Germany), and sodium hydroxide $(\mathrm{NaOH})$ at greater than $97.0 \%$ purity (Junsei Chemicals Co., Ltd., Japan) were used for treatment processes. Distilled water (DW) was used as a base fluid to make nanofluids.

\subsection{Instruments and Characterization}

Morphological analysis was performed using transmission electron microscopy (TEM; JEM-2100 F, JEOL Ltd., Japan). The structural characteristics were assessed through Fourier transform infrared (FTIR) spectral data in the $500-4000 \mathrm{~cm}^{-1}$ range (VERTEX 80v series, Bruker Co., Ltd., Korea). The dispersion and stability of nanofluids were measured with 
a UV/Vis spectrophotometer (X-ma 3000 Series Spectrophotometer, Human Co., Ltd., Korea) operating at wavelengths ranging from 250 to $900 \mathrm{~nm}$ and a zeta potential analyzer (Malvern Zetamaster, Malvern Instrument Ltd., UK). The thermal conductivity of the nanofluids was assessed using the hot wire transient method with a thermal conductivity analyzer (LAMBDA, F5 Technologies $\mathrm{GmbH}$, Willingshausen, Germany) operating at temperature ranges from 20 to $40^{\circ} \mathrm{C}$, with an interval of $5{ }^{\circ} \mathrm{C}$. The electrical conductivity of nanofluids was measured using a conductivity meter (Model CM-25R, DKK-TOA Co., Ltd., Japan).

\subsection{Functionalization of MWCNTs}

The functionalization of MWCNTs was performed using two different oxidation methods, namely acid treatment and alkaline treatment.

For acid treatment, the surfaces of MWCNTs were modified with a 1:3 volume ratio of concentrated nitric acid $\left(\mathrm{HNO}_{3}\right)$ and sulfuric acid $\left(\mathrm{H}_{2} \mathrm{SO}_{4}\right)$. Then, $1 \mathrm{~g}$ raw MWCNTs was suspended in a $40 \mathrm{~mL}$ mixture of acids via ultrasonication (1510E-DTH, Branson Ultrasonic Corporation 41, Danbury, CT 06813, USA) for $40 \mathrm{~min}$ at room temperature. Next, the oxidation reaction was performed at $100{ }^{\circ} \mathrm{C}$ for $100 \mathrm{~min}$ on a magnetic stirrer (hot plate stirrer, SMSH-20A, Scilab Korea., Ltd.). The acidic mixture of MWCNTs containing carboxyl radicals was diluted by distilled water. The sample was filtered and washed until the $\mathrm{pH}$ value reached 7.0, then it was dried in a furnace [34]. The acid-treated sample was designed as A-CNT.

For alkaline treatment, surface modification of MWCNTs was performed with potassium persulfate $\left(\mathrm{K}_{2} \mathrm{~S}_{2} \mathrm{O}_{8}\right)$. Then, $1 \mathrm{~g}$ pristine MWCNTs and $40 \mathrm{~mL}$ distilled water were added to a flask and dispersed with ultrasonic bath for $40 \mathrm{~min}$. Next, $4 \mathrm{~g} \mathrm{~K}_{2} \mathrm{~S}_{2} \mathrm{O}_{8}$ was added to the flask and the $\mathrm{pH}$ of the reaction system was adjusted to 13 by adding a concentrated $\mathrm{NaOH}$ solution. The flask equipped with a reflux condenser and a magnetic stirrer was kept at $85^{\circ} \mathrm{C}$ with mixing for $2 \mathrm{~h}$ and then cooled down to room temperature. The contents of the flask were separated by a membrane filter and rinsed with distilled water until a $\mathrm{pH}$ of 7 was reached. Lastly, the functionalized MWCNTs were dried in the furnace [33]. The alkaline-treated sample was designed as K-CNT. Figure 1 shows a schematic of the treatment processes. The treated MWCNTs were used for next step of the experiment.
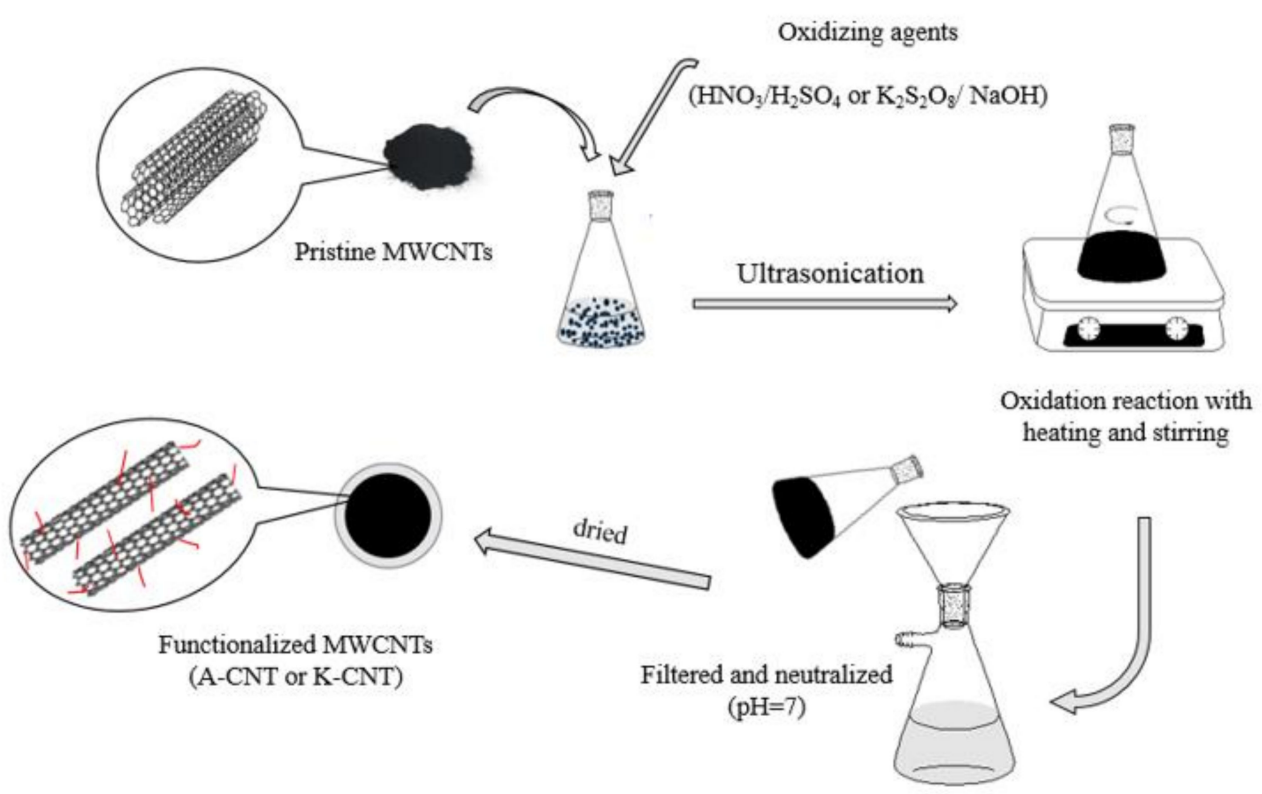

Figure 1. Schematic of the treatment processes. 


\subsection{Milling of MWCNTs}

A ball mill is one of the most useful methods for the mixing and grinding of raw materials in both laboratory and industry settings [35,36]. A planetary ball mill (HPM-700, Haji Engineering, Korea) was used to grind and shorten the CNTs. There were some factors we needed to be considered. First, the size of the grinding ball. Smaller balls increase the number of contact points between balls during the grinding process. However, the grinding performance decreases due to a reduction of kinetic collision energy [37]. Then, regarding the speed of rotation, higher speeds make the balls move strongly and violently, leading to greater improvements of the grinding efficiency [38]. Finally, the grinding time must be considered, since it is known that the size of the particles decreases with an increase in time [39]. Munkhbayar et al. [40] compared the dry and wet grinding conditions at various rotation speeds (200-500 RPM) of a planetary ball mill regarding the dispersion characteristics of MWCNTs in aqueous solution. It was found that the ground particles under the wet conditions and high rotation speed showed good dispersion in the suspension. Based on the previously published literature [40], mono-sized ( $3.0 \mathrm{~mm})$ spherical zirconia ( $\mathrm{ZrO} 2)$ balls were used as the collision medium in this study, the milling process performed under wet conditions for $1 \mathrm{~h}$, and the agitator-applied rotation speed was 500 RPM. The details of the grinding process were previously described elsewhere [40].

\subsection{Preparation of MWCNT Nanofluids}

The milling process was performed under wet conditions at a rotation speed of 500 RPM for $1 \mathrm{~h}$ on raw and previously treated MWCNT structures (CNT, A-CNT, and $\mathrm{K}-\mathrm{CNT}$ ). Then, MWCNT nanoparticles were dispersed in distilled water without any surfactant by ultrasonication (Branson Ultrasonication Corporation 41, Danbury, CT 06813, USA) for $40 \mathrm{~min}$ [15]. All of the nanofluids were prepared at a concentration of $0.1 \mathrm{wt} \%$. The dispersion characteristics of MWCNT nanofluids were analyzed using a UV-Vis spectrometer and zeta potential analyzer. The lambda system measured the thermal conductivity of the nanofluid.

\section{Result and Discussion}

\subsection{Morphological Surface Analysis of MWCNTs}

The morphological characteristics of MWCNTs were observed by TEM in this study. Figure 2 shows the TEM images of raw MWCNTs and functionalized MWCNTs under two different conditions. Some particle impurities remained on the carbon nanotube surfaces due to the synthesis process (white arrows in Figure 2A) [41]. In this study, the mixture of concentrated acids and potassium persulfate as the oxidant was used for the treatment processes. Therefore, the structure impurities were removed from MWCNTs and the tips of the nanotubes opened after the chemical processes, which can be clearly seen in Figure 2B,C.
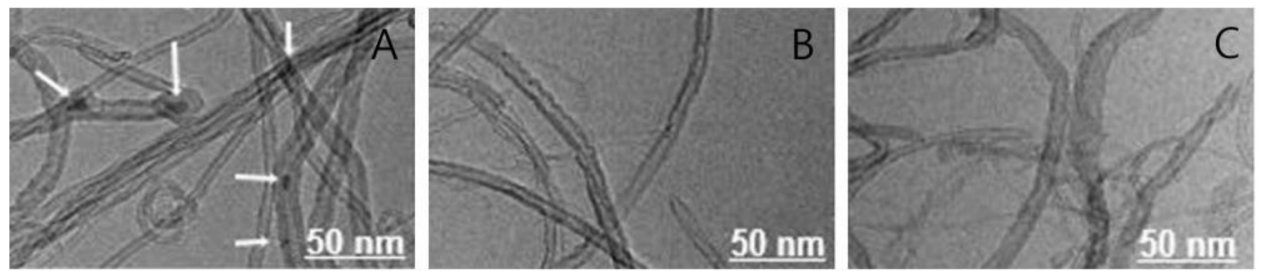

Figure 2. TEM images of the raw and functionalized MWCNTs: (A) raw CNT; (B) A-CNT; (C) K-CNT.

The structural study and the confirmation of the functional groups were carried out using FTIR spectroscopy. FTIR is mainly performed as a qualitative technique for the evaluation of functional groups. Figure 3 shows the FTIR spectra of raw MWCNTs and functionalized MWCNTs under two different conditions. The trends in the FTIR spectrum 
in Figure 3 were similar, providing similar oxygen functional groups, however the peak strength was different.

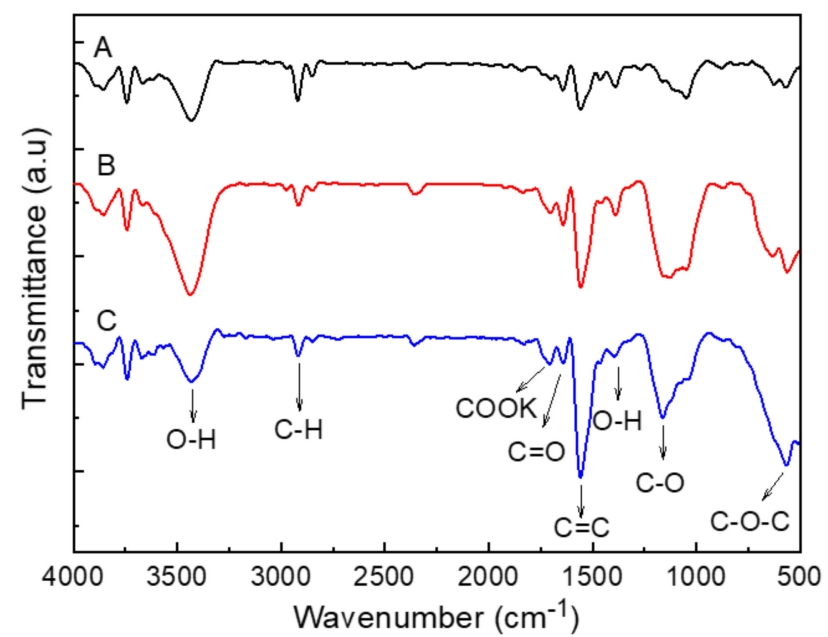

Figure 3. FTIR spectra of pristine and functionalized MWCNTs: (A) raw CNT; (B) A-CNT; (C) K-CNT.

The peaks around $3430 \mathrm{~cm}^{-1}$ can be attributed to $\mathrm{O}-\mathrm{H}$ vibrations in the hydroxyl and carboxyl formed after surface treatment processes [34,42]. The $\mathrm{O}-\mathrm{H}$ stretching intensity of A-CNT was stronger than K-CNT. Potassium persulfate was used for alkaline treatment, so potassium carboxylate (COOK) functional groups were attached to the surfaces of CNTs. Therefore, the O-H stretching intensity was lightly decreased for K-CNT as compared to A-CNT. The bands around $2800-2900 \mathrm{~cm}^{-1}$ were caused by the $\mathrm{C}-\mathrm{H}$ asymmetric and symmetric stretching vibration derived from a long alkyl chain [43]. The absorption peak around at $1715 \mathrm{~cm}^{-1}$ corresponded to the stretching vibration of $\mathrm{C}=\mathrm{O}$ from the carboxylic groups. A characteristic carbonyl peak was also observed around $1635 \mathrm{~cm}^{-1}$ and was assigned to the carbonyl group from quinine or the ring structure [22], which shows the low intensity in all of the MWCNT structures. The appearance of the peak around $1550 \mathrm{~cm}^{-1}$ showed the existence of carbon double bonding $(C=C)$, revealing the structure of pristine MWCNTs [33], while the peak intensity was increased in all treated MWCNT structures. [44]. We observed that impurities such as amorphous carbon were completely removed from the surfaces of MWCNTs after the treatment processes, and for that reason peak the intensity was increased. The peaks around $1100 \mathrm{~cm}^{-1}$ corresponded to the $\mathrm{C}-\mathrm{O}$ stretching mode of the carboxylic acid group, which had a strong intensity in each modified structure of the MWCNTs [22]. The peaks around $600 \mathrm{~cm}^{-1}$ can be assigned to stretching vibration of $\mathrm{C}-\mathrm{O}-\mathrm{C}$ groups [34]. These peaks indicated the successful generation of oxygen functional groups on the nanotubes [34,41].

\subsection{Dispersion Characteristics of MWCNTs}

Uniform dispersion and stable suspension of nanoparticles in the dispersing media are essential for the applications and final properties of the nanofluids [45,46]. The dispersion of carbon nanotubes can be characterized using UV-Vis spectroscopy [45-49]. Figure 4A shows UV-Vis spectra of suspended pristine and different chemically treated MWCNTs with and without mechanical milling. Two different chemical treatments were employed in the surface modification process, which significantly improved the dispersion of MWCNTs in this study. Chemically treated MWCNTs had significantly improved dispersion when compared to the raw MWCNT suspension. The introduction of oxygen functional groups at nanotube defect sites increases the hydrophilicity of the carbon nanotubes [50-53], Hydrophilic materials are more efficiently dispersed in aqueous solution; hence, the dispersion of CNTs was greatly improved. Additionally, the van der Waals forces between nanotubes decreased due to the attachment of functional groups, facilitating the separation of nanotube bundles into individual nanotubes [54]. This indicated that the functionalization is 
essential for the dispersion of MWCNT nanofluids. Further, utilization of the milling process provides improved dispersion of the MWCNT nanofluids. Our previously published studied [40] investigated the planetary ball milling effects on the dispersibility and thermal conductivity of CNTs in aqueous solution. As a result, it was found that the length of the CNTs shortened after grinding, as proven by particle size analysis. The agglomeration propensity was decreased and MWCNTs fibers were shortened by planetary ball milling. Small particles are better dispersed in dispersion media than large particles.
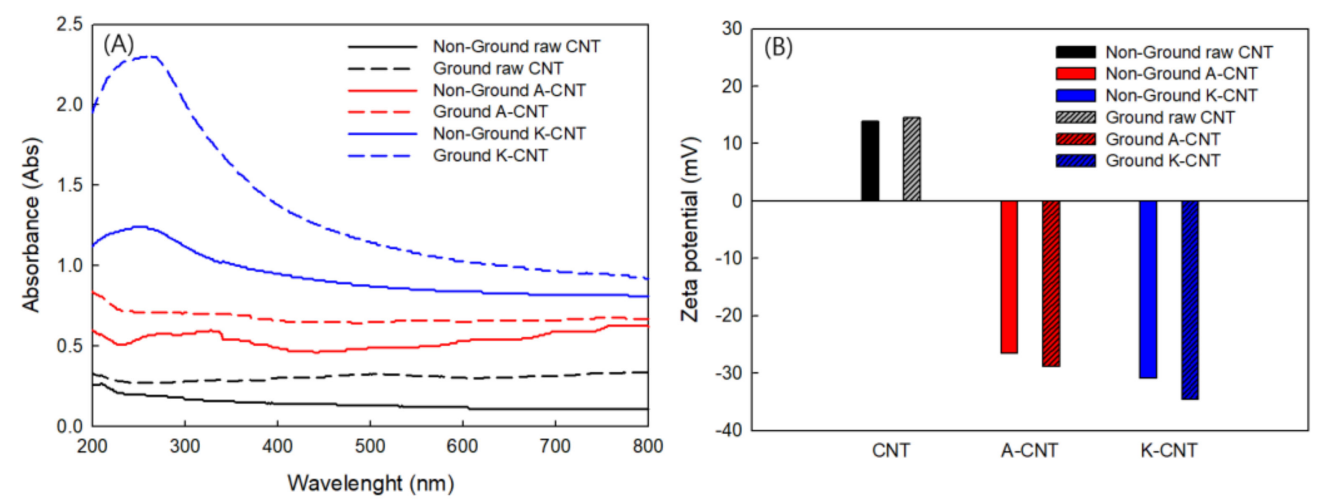

Figure 4. UV-Vis spectra (A) and zeta potential (B) comparison of non-ground and ground MWCNT nanofluids for raw and functionalized MWCNTs.

Additionally, the zeta potential is a key indicator of the stability of colloidal dispersions. The magnitude of the zeta potential indicates the degree of electrostatic repulsion between similarly charged adjacent particles in the suspension, so suspensions with high zeta potentials (negative or positive) indicate electrically stabilized particles, while colloids with low zeta potentials tend to coagulate or agglomerate [55]. The zeta potentials of pristine MWCNTs and surface-modified MWCNT suspensions with milling effects are shown in Figure 4B. After oxidative treatment of the pristine MWCNTs, the zeta potential of the nanofluid changed from positive to negative due to the formation of negatively charged oxygen functional groups on the surfaces of the MWCNTs. The magnitude of the zeta potential of functionalized MWCNT nanofluid greatly increased compared to pristine MWCNT nanofluid. Electrostatic repulsion between the nanotubes increased due to the formation of functional groups on the surfaces of MWCNTs; therefore, agglomeration of MWCNTs was reduced, however the stability of the MWCNT nanofluid was maintained. In addition, the zeta potential of milled and pristine MWCNTs was compared in aqueous solution (Figure 4B). The zeta potential of milled MWCNT nanofluid was slightly higher compared to the raw MWCNT nanofluids. The increase of the zeta potential was due to the lighter weight of the MWCNTs particles, the shortened lengths, and the reduced agglomeration that resulted from the milling process. In this study, the zeta potential of the raw MWCNT suspension was $13.87 \mathrm{mV}$ (positive). After functionalization and milling processes, the zeta potentials increased to $28.8 \mathrm{mV}$ and $34.6 \mathrm{mV}$ (negative) for milled A-CNT and K-CNT nanofluids, respectively. When the particle size is small enough, high electrostatic repulsion will confer stability. In suspensions where the zeta potential is close to zero (isoelectric point), particles tend to agglomerate. At highly negative or positive zeta potential values (more than $30 \mathrm{mV}$ or less than $-30 \mathrm{mV}$ ), particles in the suspension tend to repel each other and no agglomeration occurs [56].

Figure 5 shows photographs of the samples at different timepoints. The raw MWCNTs agglomerated rapidly after sonication-agglomeration of A-CNT started after 1 day. The $\mathrm{K}-\mathrm{CNT}$ nanofluid was stable with no visible aggregation even after one month. From the UV-Vis spectra, zeta potential, and visible tests, the dispersion characteristics of K-CNT were higher than A-CNT. For K-CNT, the $\mathrm{K}_{2} \mathrm{~S}_{2} \mathrm{O}_{8}$ oxidant generated potassium carboxyl groups $(\mathrm{COOK})$ on the exterior of the nanotubes, whereas carboxyl groups $(\mathrm{COOH})$ were generated on nanotubes after acid treatment. Zhang et al. [57] revealed that the $\mathrm{COOH}$ 
on nanotube surfaces is not easily ionized in aqueous solution as compared to COOK; therefore, COOK functional groups are strongly ionized. The hydrophilic nanotubes most probably resulted from the formation of COOK under alkaline treatment. The greatest dispersion characteristics were obtained for milled K-CNT. Therefore, the combination of alkaline treatment and the milling method were more effective for improving dispersion.

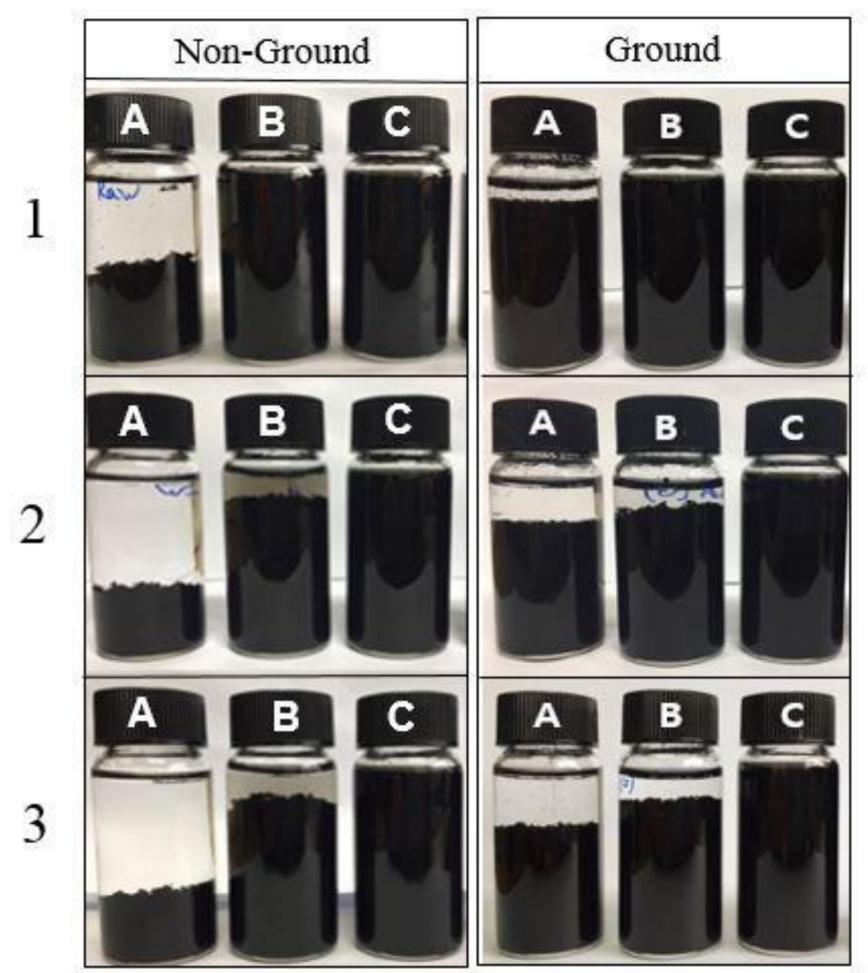

Figure 5. Photographs of pristine and functionalized MWCNT nanofluids for non-ground and ground MWCNTs: (A) raw CNT; (B) A-CNT; (C) K-CNT; (1) after sonication; (2) after 7 days; (3) after 30 days.

\subsection{Thermal Conductivity of MWCNTs}

The thermal conductivity of the fluid is an important transport property in terms of the practical applications. The thermal conductivity of nanofluids with respect to temperature is presented in this section. The LAMBDA system was calibrated with DW before the measurement. The calibration result was compared with the reference data presented in the standard textbook [58]. As shown in Figure 6, the result shows relatively good concurrence between the measurement and reference values-the measurement uncertainty was within $0.4 \%$.

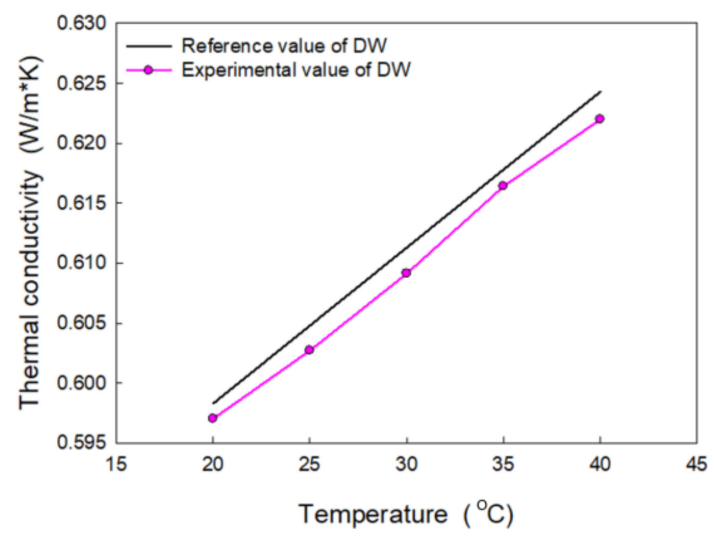

Figure 6. Thermal conductivity measurements of distilled water: experimental data and reference data. 
The thermal conductivity was determined as a function of temperature for each MWCNT nanofluid (Figure 7A). The thermal conductivity increased with increasing temperature. As the temperature increased, the viscosity of the nanofluid decreased because of an increase in the Brownian motion of the nanoparticles [59]. It was shown that the thermal conductivity increased due to convection, such as effects the induced by Brownian motion.
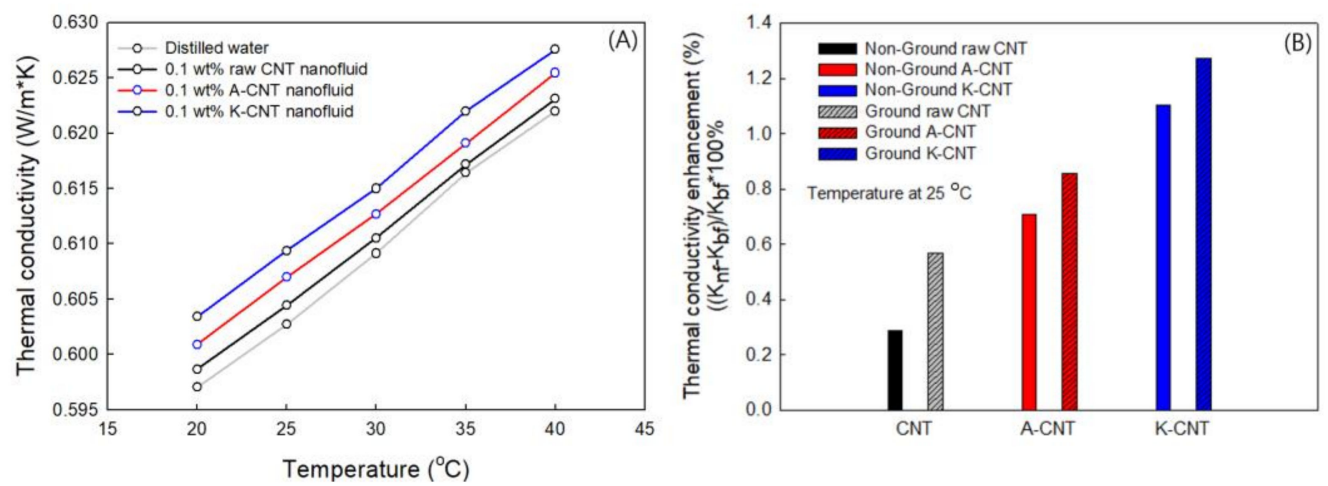

Figure 7. Thermal conductivity of non-ground (A), ground and non-ground (B) MWCNT nanofluids for pristine and functionalized MWCNTs.

The thermal conductivity of the functionalized MWCNT suspension resulting from two different chemical treatments was increased as compared to the raw MWCNT suspension, as shown in Figure 7A. The thermal conductivity of the raw MWCNT nanofluids at a concentration $0.1 \mathrm{wt} \%$ were enhanced from 603.5 to 606.9 and $609.4 \mathrm{~mW} / \mathrm{m} \cdot \mathrm{K}$ at $25^{\circ} \mathrm{C}$ for $\mathrm{A}-\mathrm{CNT}$ and K-CNT, respectively. It should be noted that the chemical functionalization significantly improved the dispersion and stability of MWCNTs, thereby increasing the thermal conductivity [60].

Figure 7B shows a comparison of the thermal conductivity levels of pristine and milled MWCNT nanofluids at $25^{\circ} \mathrm{C}$. After milling processes, the thermal conductivity was slightly increased in each MWCNT nanofluid. The improvement of thermal conductivity can be explained by the increase of the specific surface area of the suspended nanostructure due to a decrease of the size of the agglomerated particles by the milling process. The shape and dimensions of nanoparticles can be affected by the thermal conductivity of the nanofluid [54]. It has been shown that shortening of the length of nanotubes and decreasing particle size are important steps in terms of the magnitude of thermal conductivity enhancement. The thermal transfer of the short structures can be faster than for long particles [61], meaning that energy transport inside the liquid is strong and the thermal conductivity increases. The greatest thermal conductivity enhancement obtained for the ground K-CNT was $1.3 \%$ $(0.610 \mathrm{~W} / \mathrm{m} \cdot \mathrm{K}$ ) compared to base fluid (water $0.602 \mathrm{~W} / \mathrm{m} \cdot \mathrm{K}$ ).

\subsection{Electrical Conductivity of MWCNTs}

The electrical conductivity is a unique property for electromechanical devices and microelectronics. To confirm the dispersion characteristics, an electrical conductivity experiment was conducted in this study. Each MWCNT structure was analyzed. Before the electrical conductivity measurement, the calibration was applied with a potassium chloride standard $(1.41,12.86 \mu \mathrm{S} / \mathrm{cm})$ solution.

Figure $8 \mathrm{~A}$ shows the electrical conductivity of the nanofluids at $0.1 \mathrm{wt} \%$ concentration as a function of temperature. The electrical conductivity increased with increasing temperature for the treated MWCNT nanofluids. The electrical conductivity of functionalized MWCNT nanofluids was higher than for the raw MWCNT nanofluid. 

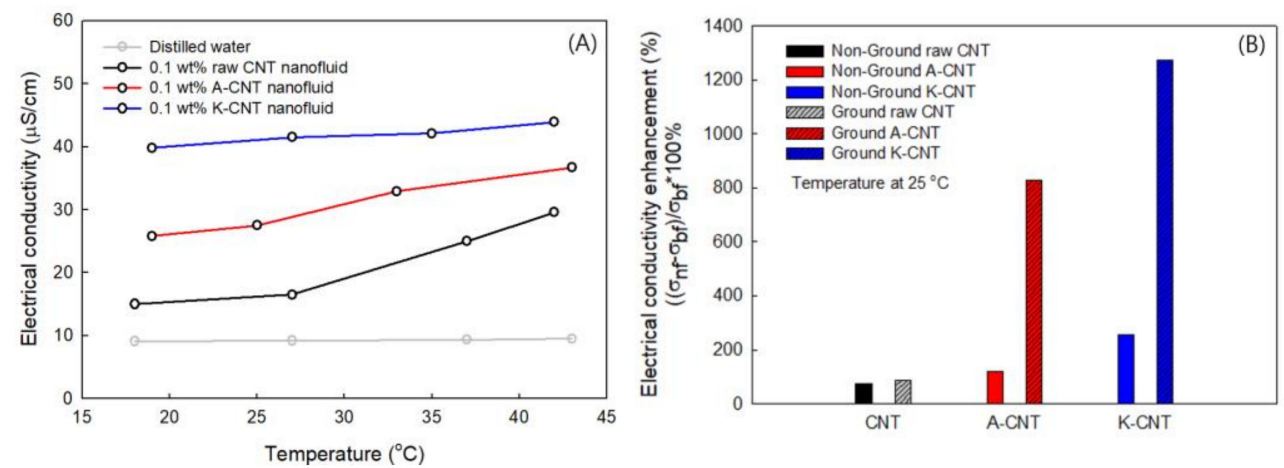

Figure 8. Electrical conductivity of non-ground (A), ground and non-ground (B) MWCNT nanofluids for pristine and functionalized MWCNTs.

An important factor affecting the electrical conductivity is the agglomeration of the nanoparticles in the base fluid [62]. The chemical functionalization significantly reduced the agglomeration of MWCNTs, thereby increasing the electrical conductivity. The electrical conductivity of the MWCNT nanofluid at a concentration of $0.1 \mathrm{wt} \%$ was enhanced from 16.19 to 27.4 and $41.2 \mu \mathrm{S} / \mathrm{cm}$ at $25^{\circ} \mathrm{C}$ for A-CNT and $\mathrm{K}-\mathrm{CNT}$, respectively. The highest electrical conductivity was determined for K-CNT. Therefore, alkaline treatment is more effective for increasing electrical conductivity, meaning that it showed the same result as for the thermal conductivity.

Figure $8 \mathrm{~B}$ shows a comparison of the electrical conductivity enhancement of nonmilled and milled MWCNT nanofluids at $25^{\circ} \mathrm{C}$. After the milling processes, the electrical conductivity was significantly increased for each treated MWCNT nanofluid. The percentage enhancement in electrical conductivity was calculated using the formula $\left[\left(\sigma_{1}-\sigma_{0}\right) / \sigma\right] \times 100 \%$, where " $\sigma_{0}$ " corresponds to the electrical conductivity of the base fluid and " $\sigma_{1}$ " corresponds to the electrical conductivity of the nanofluid. The highest enhancement was $1275 \%$ for the milled K-CNT, with a mass fraction of $0.1 \%$ at $25^{\circ} \mathrm{C}$. It can be deduced that the improvement of the dispersion characteristics and the increase in the electrical conductivity are attributable to the increase of the surface area and electrophoretic mobility of the particles [63-65].

In this work, it was successfully found that alkaline functionalization and milling processes can effectively promote reduced agglomeration, increased dispersion, and longterm maintenance of the stability of MWCNT nanofluids, thereby improving the properties of MWCNT nanofluids.

Finally, details of the result are shown in Table 1, corresponding to the experimental conditions.

Table 1. Characteristics of the pristine and surface-modified MWCNTs.

\begin{tabular}{|c|c|c|c|c|c|c|}
\hline No. & Sample & Type of Agent & Conc. $(w t \%)$ & $\begin{array}{l}\text { Zeta Pot. } \\
(\mathrm{mV})\end{array}$ & $\begin{array}{l}\text { Thermal Cond. } \\
(\mathrm{W} / \mathrm{m} \cdot \mathrm{K}) \text { at } 25^{\circ} \mathrm{C}\end{array}$ & $\begin{array}{l}\text { Electrical Cond. } \\
(\mu \mathrm{S} / \mathrm{cm}) \text { at } 25^{\circ} \mathrm{C}\end{array}$ \\
\hline 1 & $\begin{array}{c}\text { Non-ground Pristine } \\
\text { CNT }\end{array}$ & - & 0.1 & 13.87 & 0.6035 & 16.19 \\
\hline 2 & $\begin{array}{c}\text { Ground } \\
\text { Pristine CNT }\end{array}$ & - & 0.1 & 14.54 & 0.6061 & 17.32 \\
\hline 3 & Non-ground A-CNT & $\mathrm{H}_{2} \mathrm{SO}_{4} / \mathrm{HNO}_{3}$ & 0.1 & -26.6 & 0.6069 & 20.2 \\
\hline 4 & Ground A-CNT & $\mathrm{H}_{2} \mathrm{SO}_{4} / \mathrm{HNO}_{3}$ & 0.1 & -28.83 & 0.6078 & 85.1 \\
\hline 5 & Non-ground K-CNT & $\mathrm{K}_{2} \mathrm{~S}_{2} \mathrm{O}_{8} / \mathrm{NaOH}$ & 0.1 & -30.9 & 0.6094 & 32.7 \\
\hline 6 & Ground K-CNT & $\mathrm{K}_{2} \mathrm{~S}_{2} \mathrm{O}_{8} / \mathrm{NaOH}$ & 0.1 & -34.57 & 0.6104 & 125.8 \\
\hline
\end{tabular}




\section{Conclusions}

In this experimental study, surface modifications under different conditions (acid and alkaline treatment) and milling processed were investigated regarding their effects on the dispersion characteristics of the thermal and electrical conductivity of the MWCNTs in aqueous solution.

From the obtained results, the functionalized and ground MWCNTs showed higher dispersion characteristics as compared to the raw MWCNT nanofluid. The dispersion characteristics of the nanofluids were increased by treatment and ball milling processes. The greatest thermal conductivity enhancement for MWCNTs was $1.3 \%(0.610 \mathrm{~W} / \mathrm{m} \cdot \mathrm{K})$ as compared to the base fluid (distilled water $0.602 \mathrm{~W} / \mathrm{m} \cdot \mathrm{K}$ ) for the ground $\mathrm{K}-\mathrm{CNT}$ at $25^{\circ} \mathrm{C}$. The greatest electrical conductivity enhancement for MWCNTs was $1275 \%(125.8 \mu \mathrm{S} / \mathrm{cm})$ compared to the base fluid $(9.15 \mu \mathrm{S} / \mathrm{cm})$ for the ground $\mathrm{K}-\mathrm{CNT}$ at $25^{\circ} \mathrm{C}$. The results indicated that the properties of alkaline-treated MWCNTs were better than acid-treated MWCNTs. Therefore, the alkaline method is more effective, environmentally friendly, and convenient for the preparation of CNT nanofluids and does not require the use of organic solvents or strong acids. Functionalization alone was not sufficient to improve the dispersion of CNTs in the base fluid. Use of the functionalization and ball milling methods together was necessary to improve dispersion and thermal and electrical conductivity of the MWCNT nanofluids.

Author Contributions: B.T. and H.J.; conceptualization, S.K.; data curation, S.K.; formal analysis, methodology, B.T. and H.J.; investigation, B.T. and E.D.; validation, resources; B.T.; writing—original draft, A.D.; supervision, S.K. and A.D.; writing-review and editing. All authors have read and agreed to the published version of the manuscript.

Funding: This research was supported by the Basic Science Research Program through the National Research Foundation of Korea (NRF), funded by the Ministry of Science, ICT, and Future Planning (No. 2017R1A2B4007620).

Data Availability Statement: Data is contained within the article.

Conflicts of Interest: The authors declare no conflict of interest.

\section{References}

1. Moore, V.C.; Strano, M.S.; Haroz, E.H.; Hauge, R.H.; Smalley, R.E.; Schmidt, J.; Talmon, Y. Individually suspended single-walled carbon nanotubes in various surfactants. Nano Lett. 2003, 3, 1379-1382. [CrossRef]

2. Baughman, R.H.; Zakhidov, A.A.; De Heer, W.A. Carbon nanotubes-The route toward applications. Science 2002, 297, 787-792. [CrossRef] [PubMed]

3. Vaccarini, L.; Goze, C.; Henrard, L.; Hernandez, E.; Bernier, P.; Rubio, A. Mechanical and electronic properties of carbon and boron-nitride nanotube. Carbon 2000, 38, 1681-1690. [CrossRef]

4. Casas, C.; Li, W. A review of application of carbon nanotubes for lithium ion battery anode material. J. Power Sources 2012, 208, 74-85. [CrossRef]

5. Chahine, N.O.; Collette, N.M.; Thomas, C.B.; Genetos, D.C.; Loots, G.G. Nanocomposite scaffold for chondrocyte growth and cartilage tissue engineering: Effects of carbon nanotube surface functionalization. Tissue Eng. Part A 2014, 20, $2305-2315$. [CrossRef] [PubMed]

6. Apul, O.G.; Wang, Q.; Zhou, Y.; Karanfil, T. Adsorption of aromatic organic contaminants by graphene nanosheets: Comparison with carbon nanotubes and activated carbon. Water Res. 2013, 47, 1648-1654. [CrossRef]

7. Sahooa, N.G.; Ranab, S.; Cho, J.W.; Li, L.; Chana, S. Polymer nanocomposites based on functionalized carbon nanotubes. Prog. Polym. Sci. 2010, 35, 837-867. [CrossRef]

8. Postma, H.W.C.; Teepen, T.; Yao, Z.; Grifoni, M.; Dekker, C. Carbon nanotube single-electron transistors at room temperature. Science 2001, 293, 76-79. [CrossRef]

9. Cherukuri, P.; Bachilo, S.M.; Litovsky, S.H.; Weisman, R.B. Near-infrared fluorescence microscopy of single-walled carbon nanotubes in phagocytic cells. J. Am. Chem. Soc. 2004, 126, 15638-15639. [CrossRef]

10. Guldi, D.M.; Rahman, G.M.A.; Prato, M.; Jux, N.; Qin, S.; Ford, W. Single-wall carbon nanotubes as integrative building blocks for solar-energy conversion. Angew. Chem. 2005, 117, 2051-2054. [CrossRef]

11. Dillon, A.C.; Jones, K.M.; Bekkedahl, T.A.; Kiang, C.H.; Bethune, D.S.; Heben, M.J. Storage of hydrogen in single-walled carbon nanotubes. Nat. Cell Biol. 1997, 386, 377-379. [CrossRef] 
12. Jiang, W.; Ding, G.; Peng, H. Measurement and model on thermal conductivities of carbon nanotube nanorefrigerants. Int. J. Therm. Sci. 2009, 48, 1108-1115. [CrossRef]

13. Hwang, Y.J.; Ahn, Y.C.; Shin, H.S.; Lee, C.G.; Kim, G.T.; Park, H.S.; Lee, J.K. Investigation on characteristics of thermal conductivity enhancement of nanofluids. Cur. Appl. Phys. 2006, 6, 1068-1071. [CrossRef]

14. Munkhbayar, B.; Hwang, S.; Kim, J.; Bae, K.; Ji, M.; Chung, H.; Jeong, H. Photovaltiac performance of dye-sensitized solar cells with various MWCNT counter electrode structures produced by different coating methods. Electochimica Acta 2012, 80, 100-107. [CrossRef]

15. Garg, P.; Alvarado, J.L.; Marsh, C.; Carlson, T.A.; Kessler, D.A.; Annamalai, K. An experimental study on the effect of ultrasonication viscosity and heat transfer performance of multi-wall carbon nanotube-based aqueous nanofluids. Int. J. Heat Mass Transf. 2009, 52, 5090-5101. [CrossRef]

16. Krause, B.; Villmow, T.; Boldt, R.; Mende, M.; Petzold, G.; Pötschke, P. Influence of dry grinding in a ball mill on the length of multiwalled carbon nanotubes and their dispersion and percolation behaviour in melt mixed polycarbonate composites. Compos. Sci. Technol. 2011, 71, 1145-1153. [CrossRef]

17. Wen, D.S.; Ding, Y.L. Effective thermal conductivity of aqueous suspension of carbon nanotubes. J. Thermophys. Heat Transf. 2004, 18, 481-485. [CrossRef]

18. Huxtable, S.T.; Cahill, D.G.; Shenogin, S.; Xue, L.; Ozisik, R.; Barone, P.; Usrey, M.; Strano, M.S.; Siddons, G.; Shim, M.; et al. Interfacial heat flow in carbon nanotube suspensions. Nat. Mater. 2003, 2, 731-734. [CrossRef]

19. Katkova, M.A.; Zabrodina, G.S.; Kremlev, K.V.; Gusev, S.A.; Obiedkov, A.M. Effect of Ce(III)-Cu(II) 15-metallacrown-5 compounds on the dispersion of multi-walled carbon nanotubes in aqueous solutions: Toward surfactant-free applications. Thin Solid Film. 2017, 628, 112-116. [CrossRef]

20. Kim, S.; Tserengombo, B.; Choi, S.H.; Noh, J.; Huh, S.; Choi, B.; Chung, H.; Kim, J.; Jeong, H. Experimental investigation of dispersion characteristics and thermal conductivity of various surfactants on carbon based material. Int. Comm. Heat Mass Trans. 2018, 91, 95-102. [CrossRef]

21. Riggs, J.E.; Guo, Z.; Carrol, D.L.; Sun, Y.P. Dispersion of carbon nanotubes and their polymer composites. J. Am. Chem. Soc. 2000, $104,7071-7076$.

22. Wei, J.; Lv, R.; Guo, N.; Wang, H.; Bai, X.; Mathkar, A.; Kang, F.; Zhu, H.; Wang, K.; Wu, D.; et al. Preparation of highly oxidized nitrogen-doped carbon nanotubes. Nanotechnology 2012, 23, 155601-155606. [CrossRef] [PubMed]

23. Kim, B.; Sigmund, W.M. Functionalized multiwall carbon nanotube/gold nanoparticle composites. Langmuir 2004, 20 , 8239-8242. [CrossRef]

24. Cuentas-Gallegos, A.K.; Martínez-Rosales, R.; Rincón, M.E.; Hirata, G.A.; Orozco, G. Design of hybrid materials based on carbon nanotubes and polyoxometalates. Opt. Mater. 2006, 29, 126-133. [CrossRef]

25. Datye, A.; Wu, K.-H.; Gomes, G.; Monroy, V.; Lin, H.-T.; Vleugels, J.; Vanmeensel, K. Synthesis, microstructure and mechanical properties of Yttria Stabilized Zirconia (3YTZP)—Multi-Walled Nanotube (MWNTs) nanocomposite by direct in-situ growth of MWNTs on Zirconia particles. Compos. Sci. Technol. 2010, 70, 2086-2092. [CrossRef]

26. Eder, D. Carbon nanotube-inorganic hybrids. Chem. Rev. 2010, 110, 1348-1352. [CrossRef]

27. Flahaut, E.; Peigney, A.; Laurent, C.; MarlieRe, C.; Chastel, F.; Rousset, A. Carbon nanotube-metal-oxide nanocomposites: Microstructure, electrical conductivity and mechanical properties. Act. Mater. 2000, 48, 3803-3812. [CrossRef]

28. Goering, J.; Kadossov, E.; Burghaus, U. Adsorption Kinetics of Alcohols on Single-Wall Carbon Nanotubes: An ultrahigh vacuum surface chemistry study. J. Phys. Chem. C 2008, 112, 10114-10124. [CrossRef]

29. Gong, J.-L.; Wang, B.; Zeng, G.-M.; Yang, C.-P.; Niu, C.-G.; Niu, Q.-Y.; Zhou, W.-J.; Liang, Y. Removal of cationic dyes from aqueous solution using magnetic multi-wall carbon nanotube nanocomposite as adsorbent. J. Hazard. Mater. 2009, 164, 1517-1522 [CrossRef]

30. Avilés, F.; Cauich-Rodríguez, J.; Moo-Tah, L.; May-Pat, A.; Vargas-Coronado, R. Evaluation of mild acid oxidation treatments for MWCNT functionalization. Carbon 2009, 47, 2970-2975. [CrossRef]

31. Rosca, I.D.; Watari, F.; Uo, M.; Akasaka, T. Oxidation of multiwalled carbon nanotubes by nitric acid. Carbon 2005, 43, 3124-3131 [CrossRef]

32. Nasiri, A.; Shariaty-Niasar, M.; Rashidi, A.; Khodafarin, R. Effect of CNT structures on thermal conductivity and stability of nanofluid. Int. J. Heat Mass Transf. 2012, 55, 1529-1535. [CrossRef]

33. Ghozatloo, A.; Shariaty-Niasar, M.; Rashidi, A.M. Preparation of nanofluids from functionalized Graphene by new alkaline method and study on the thermal conductivity and stability. Int. Commun. Heat Mass Transf. 2013, 42, 89-94. [CrossRef]

34. Datsyuk, V.; Kalyva, M.; Papagelis, K.; Parthenios, J.; Tasis, D.; Siokou, A.; Kallitsis, I.; Galiotis, C. Chemical oxidation of multiwalled carbon nanotubes. Carbon 2008, 46, 833-840. [CrossRef]

35. Tokmakci, T.; Ozturk, A.; Park, J. Boron and zirconium co-doped TiO2 powders prepared through mechanical ball milling. Ceram. Int. 2013, 39, 5893-5899. [CrossRef]

36. Tiwary, C.; Verma, A.; Biswas, K.; Mondal, A.K.; Chattopadhyay, K. Preparation of ultrafine CsCl crystallites by combined cryogenic and room temperature ball milling. Ceram. Int. 2011, 37, 3677-3686. [CrossRef]

37. Shin, H.; Lee, S.; Jung, H.S.; Kim, J.-B. Effect of ball size and powder loading on the milling efficiency of a laboratory-scale wet ball mill. Ceram. Int. 2013, 39, 8963-8968. [CrossRef] 
38. Mio, H.; Kano, J.; Saito, F.; Kaneko, K. Optimum revolution and rotational directions and their speeds in planetary ball milling. Int. J. Miner. Process. 2004, 74, S85-S92. [CrossRef]

39. Liu, S.-S.; Sun, L.-X.; Zhang, Y.; Xu, F.; Zhang, J.; Chu, H.-L.; Fan, M.-Q.; Zhang, T.; Song, X.-Y.; Grolier, J.P. Effect of ball milling time on the hydrogen storage properties of TiF3-doped LiAlH4. Int. J. Hydrog. Energy 2009, 34, 8079-8085. [CrossRef]

40. Munkhbayar, B.; Nine, M.J.; Jeoung, J.; Munkhjargal, B.; Chung, H.; Jeong, H. Influence of dry and wet ball milling on dispersion characteristics of the multi-walled carbon nanotubes in aqueous solution with and without surfactant. Powder Technol. 2013, 234, 132-140. [CrossRef]

41. Yudianti, R.; Onggo, H.; Sudirman; Saito, Y.; Iwata, T.; Azuma, J. Analysis of functional group sited on multi-wall carbon nanotube surface. Open Mater. Sci. J. 2011, 5, 242-247. [CrossRef]

42. Shim, J.-W.; Park, S.-J.; Ryu, S.-K. Effect of modification with $\mathrm{HNO} 3$ and $\mathrm{NaOH}$ on metal adsorption by pitch-based activated carbon fibers. Carbon 2001, 39, 1635-1642. [CrossRef]

43. Yadav, S.K.; Mahapatra, S.S.; Yoo, H.J.; Cho, J.W. Synthesis of multi-walled carbon nanotube/polyhedral oligomeric silsesquioxane nanohybrid by utilizing click chemistry. Nanoscale Res. Lett. 2011, 6, 122-128. [CrossRef] [PubMed]

44. Gupta, V.K.; Saleh, T.A. Synthesis of carbon nanotube-metal oxides composites; adsorption and photo-degradation. Carbon Nanotub. Res. Appl. 2011, 295-312.

45. Castaldo, R.; Lama, G.C.; Aprea, P.; Gentile, G.; Lavorgna, M.; Ambrogi, V.; Cerruti, P. Effect of the oxidation degree on self-assembly, adsorption and barrier properties of nano-graphene. Microporous Mesoporous Mater. 2018, 260, 102-115. [CrossRef]

46. Yan, H.; Wu, H.; Li, K.; Wang, Y.; Tao, X.; Yang, H.; Li, A.; Cheng, R. Influence of the surface structure of graphene oxide on the adsorption of aromatic organic compounds from water. ACS Appl. Mater. Interfaces 2015, 7, 6690-6697. [CrossRef]

47. McAllister, M.J.; Li, J.L.; Adamson, D.H.; Schniepp, H.C.; Abdala, A.A.; Liu, J.; Aksay, I.A.; Herrera-Alonso, M.; Milius, D.L.; Car, R.; et al. Single sheet functionalized graphene by oxidation and thermal expansion of graphite. Chem. Mater. 2007, 19, 4396-4404. [CrossRef]

48. Kang, J.H.; Kim, T.; Choi, J.; Park, J.; Kim, Y.S.; Chang, M.S.; Jung, H.; Park, K.T.; Yang, S.J.; Park, C.R. Hidden second oxidation step of hummers method. Chem. Mater. 2016, 28, 756-764. [CrossRef]

49. Qiu, Y.; Collin, F.; Hurt, R.H.; Külaots, I. Thermochemistry and kinetics of graphite oxide exothermic decomposition for safety in large-scale storage and processing. Carbon 2016, 96, 20-28. [CrossRef]

50. Bai, H.; Jiang, W.; Kotchey, G.P.; Saidi, W.A.; Bythell, B.J.; Jarvis, J.M.; Marshall, A.G.; Robinson, R.A.S.; Star, A. Insight into the mechanism of graphene oxide degradation via the photo-fenton reaction. J. Phys. Chem. C 2014, 118, 10519-10529. [CrossRef]

51. Pham, V.H.; Pham, H.D.; Dang, T.T.; Hur, S.H.; Kim, E.J.; Kong, B.S.; Kim, S.; Chung, J.S. Chemical reduction of an aqueous suspension of graphene oxide by nascent hydrogen. J. Mater. Chem. 2012, 22, 10530-10536. [CrossRef]

52. Kim, S.W.; Kim, T.; Kim, Y.S.; Choi, H.S.; Lim, H.J.; Yang, S.J.; Park, C.R. Surface modifications for the effective dispersion of carbon nanotubes in solvents and polymers. Carbon 2012, 50, 3-33. [CrossRef]

53. O'Brien, R.W.; Midmore, B.R.; Lamb, A.; Hunter, R.J. Electroacoustic studies of moderately concentrated colloidal suspensions. Faraday Discuss. Chem. Soc. 1990, 19, 301-312. [CrossRef]

54. Lee, J.H.; Rhee, K.Y.; Park, S.J. Effects of cryomilling on the structures and hydrogen storage characteristics of multi-walled carbon nanotubes. Int. J. Hydrogen Energy 2010, 35, 7850-7857. [CrossRef]

55. Greenwood, R.; Kendall, K. Electroacoustic studies of moderately concentrated colloidal suspensions. J. Eur. Ceram. Soc. 1999, 19, 479-488. [CrossRef]

56. Mandzy, N.; Grulke, E.; Druffel, T. Breakage of TiO2 agglomerates in electrostatically stabilized aqueous dispersions. Powder Technol. 2005, 160, 121-126. [CrossRef]

57. Zhang, L.; Ni, Q.-Q.; Fu, Y.; Natsuki, T. One-step preparation of water-soluble single-walled carbon nanotubes. Appl. Surf. Sci. 2009, 255, 7095-7099. [CrossRef]

58. Incropera, F.P.; DeWitt, D.P. Fundamentals of Heat and Mass Transfer, 3rd ed.; John Wiley \& Sons, Inc.: New York, NY, USA, 1996.

59. Jang, S.P.; Choi, S.U.S. Role of Brownian motion in the enhanced thermal conductivity of nanofliuds. Appl. Phys. Lett. 2004, 84, 4316-4318. [CrossRef]

60. Gao, J.; Itkis, M.E.; Yu, A.; Bekyarova, E.; Zhao, B.; Haddon, R.C. Continuous spinning of a single-walled carbon nanotube-nylon composite fiber. J. Am. Chem. Soc. 2005, 127, 3847-3854. [CrossRef]

61. Xie, H.; Chen, L. Adjustable thermal conductivity in carbon nanotube nanofluids. Phys. Lett. A 2009, 373, 1861-1864. [CrossRef]

62. Bordi, F.; Cametti, C.; Codastefano, P.; Tartaglia, P. Electrical conductivity of colloidal systems during irreversible aggregation. Phys. A Stat. Mech. Appl. 1990, 164, 663-672. [CrossRef]

63. Sarojini, K.K.; Manoj, S.V.; Singh, P.K.; Pradeep, T.; Das, S.K. Electrical conductivity of ceramic and metallic nanofluids. Colloids Surfaces A Physicochem. Eng. Asp. 2013, 417, 39-46. [CrossRef]

64. Srinivasan, B.; Le Tonquesse, S.; Gellé, A.; Bourgès, C.; Monier, L.; Ohkubo, I.; Halet, J.-F.; Berthebaud, D.; Mori, T. Screening of transition ( $\mathrm{Y}, \mathrm{Zr}, \mathrm{Hf}, \mathrm{V}, \mathrm{Nb}, \mathrm{Mo}$, and $\mathrm{Ru}$ ) and rare-earth ( $\mathrm{La}$ and $\mathrm{Pr}$ ) elements as potential effective dopants for thermoelectric GeTe-an experimental and theoretical appraisal. J. Mater. Chem. A 2020, 8, 19805-19821. [CrossRef]

65. Bourgès, C.; Srinivasan, B.; Fontaine, B.; Sauerschnig, P.; Minard, A.; Halet, J.F.; Halet, J.-F.; Miyazaki, Y.; Berthebaud, D.; Mori, T. Tailoring the thermoelectric and structural properties of $\mathrm{Cu}-\mathrm{Sn}$ based thiospinel compounds [CuM $1+x \mathrm{Sn} 1-\mathrm{x} \mathrm{S} 4(\mathrm{M}=\mathrm{Ti}, \mathrm{V}, \mathrm{Cr}$, Co)]. J. Mater. Chem. C 2020, 8, 16368-16383. [CrossRef] 